\begin{tabular}{lll}
\hline 資 料 Informational Reports \\
\hline
\end{tabular}

$\left(\begin{array}{llr}\text { Jpn. J. Hosp. Pharm. } \\ \text { 資 } \\ \text { 24(2) } & 156-162(1998)\end{array}\right)$

\title{
気管支喘息患者の薬剤ならびに疾患に対する理解度と経過
}

\author{
小嶋文良 ${ }^{*} \dagger^{1}$, 中村秀範 $\dagger^{2}$, 東海林徹 $\dagger^{1}$, 友池仁暢 $\dagger^{2}$, 仲川義人 $\dagger^{1}$ \\ 山形大学医学部附属病院薬剤部 $\dagger 1$ \\ 山形大学医学部第一内科 $\dagger^{2}$
}

\section{Understanding Levels of Medication and One's Own Disease and Clinical Course in Patients with Bronchial Asthma}

\author{
FUMIYOSHI OJIMA ${ }^{*} \dagger^{1}$, HIDENORI NAKAMURA $\dagger^{2}$, TOHRU SHOJI $\dagger^{1}$, \\ HITONOBU TOMOIKE $\dagger^{2}$ and YOSHITO NAKAGAWA $\dagger^{1}$ \\ Division of Pharmacy, Yamagata University Hospital $\dagger^{1}$
}

First Department of Internal Medicine, Yamagata University School of Medicine ${ }^{2}$

$\left(\begin{array}{l}\text { Received August 11, } 1997 \\ \text { Accepted September 24, 1997 }\end{array}\right)$

In outpatients with bronchial asthma, therapeutic events occurring before and after pharmaceutical instructions were investigated in patients having a better or poorer understanding their own disease and the medication being taken. No rehospitalization was observed in any of the patients after the pharmaceutical instructions were fully explained. The frequency of acute exacerbation required of intravenous drip of glucocorticoids and/or aminophylline were markedly decreased in a patients with a good understanding of the pharmaceutical instruction. In patients with a poor understanding, however, during the one-year period following the instructions, frequency of the exacerbations was almost the same as that before the instructions though exacerbation did not necessitate hospitalization and their clinical course improved afterwards. Our patients with bronchial asthma were able to comprehend the importance of medication with the partial improvement of symptoms resulting from carefully prescribed pharmaceutical instructions, especially with regard to the adequate use of the metered dose inhaler. Therefore, compared with the patients having other chronic diseases, patients with bronchial asthma took their medication with good compliance, along with adequate use of the metered dose inhaler despite some patients having a poor understanding of their disease and the efficacy of the medication administered.

Key words — bronchial asthma, pharmaceuitical instruction, understanding level of patients.

\author{
緒言 \\ 気管支喘息は気道全体の炎症性疾患と捉えられ \\ ており ${ }^{1,2)}$ ，その治療には抗炎症薬である副腎皮 \\ $\dagger^{1.2}$ 山形県山形市飯田西2丁目 $2-2 ; 2-2-2$, Iida-nishi, \\ Yamagata, 990-9585 Japan
}

質ステロイド剤（ステロイド）の適応疾患の一つ である。しかし，経口ステロイドは全身性の副作 用が発現しやすく，気管支喘息では定量噴霧吸入 凰 (metered dose inhaler, MDI) による吸入ステ ロイドが奨められており, 治療に重要な役割を果 たしている゙!)。しかし，内服薬と異なり，MDIは 
吸入操作の善し悪しが，治療効果に大きく影響 し，これまでにも不適切な使用法をしている患者 が多く，適切な使用法の指導が重要であると指摘 されている(-6).そのため気管支喘息患者への服 薬指導は内服薬の他に, MDI の吸入指導にも力 点を置く必要がある．気管支喘息が他の多くの慢 性疾患と異なる点は，発作の苦しさを患者自身が 自覚していることであり，その苦しさが治まり良 好にコントロールされ，治療効果を患者が自覚す ることによって薬剤や疾患に関して良く理解でき ていなくても服薬コンプライアンスがよくなる事 が期待できる，本論文では理解度が良好な患者 と，入院中に複数回指導したにもかかわらず，薬 のみならず，疾患に関しても理解度が低い患者を 対象に, 服薬指導前後の外来診療状況と治療内容 について調査し，指導後の経過に対する患者の理 解度の差異による影響ついて評価した。

\section{調 査 内 容}

カルテより, 外来受診日, 処方内容, 外来治療 室での点滴治療の有無を調べ, 受診間隔, 治療点 数を求めた。薬に関しては, 処方されている薬に ついて名前，用法，作用についての調查票を患者
に郵送し，その回答より理解度を求めた。症状悪 化による点滴治療内容はステロイド，あるいはア ミノフィリン単独療法，もしくは両者の併用によ るものであり，これらを以下点滴治療と表記す る.

\section{結果}

\section{1. 理解度の高い症例（以下症例 G）}

男性，年歯65歳，気管支喘息は混合型， 中等症に分類されており，罹患歴が 10 年，他院よ りの紹介患者であり当院では初診より 4 年経過し ていた (Table 1). 当院ではこれまで 3 回の入院 歴があり，医師より外来に扔いて指導依頼があっ た。（Fig. 1)。本症例 $\mathrm{G}$ は外来時の吸入指導依 頼であり，吸入補助器具を使用した MDI の吸入 法，交換時期，発作時の対応，さらに喘息の管理 に重要なピークフローの測定についての指導を行 った。外来患者への指導であるため，MDIの使 用法については患者に確認しないで，一方的な指 導のみになってしまった。その後の調査により， MDI の吸入療法に関して, ステロイドの吸入は 定期吸入を指示されていたにもかかわらず，呼吸 が苦しい時に合わせて吸入しており，急いで吸入

Table 1. 症例 $\mathrm{G}$ と症例 $\mathrm{P}$ の患者情報

\begin{tabular}{|c|c|c|c|c|c|c|c|}
\hline 症 田 & 槽 & 别 & 年 的 & 正越度 & 乗 & 萑 & 指㴖嵝の経迄 \\
\hline G & 冝 & 性 & 65 츤 & 中等㱏 & 湿合棐 & 10年 & 26.7ヶ月 \\
\hline $\mathbf{P}$ & 男 & 性 & $74 \vec{E}$ & 量 䇂 & 呾合瑟 & 16年 & $33.0 ヶ$ 月 \\
\hline
\end{tabular}
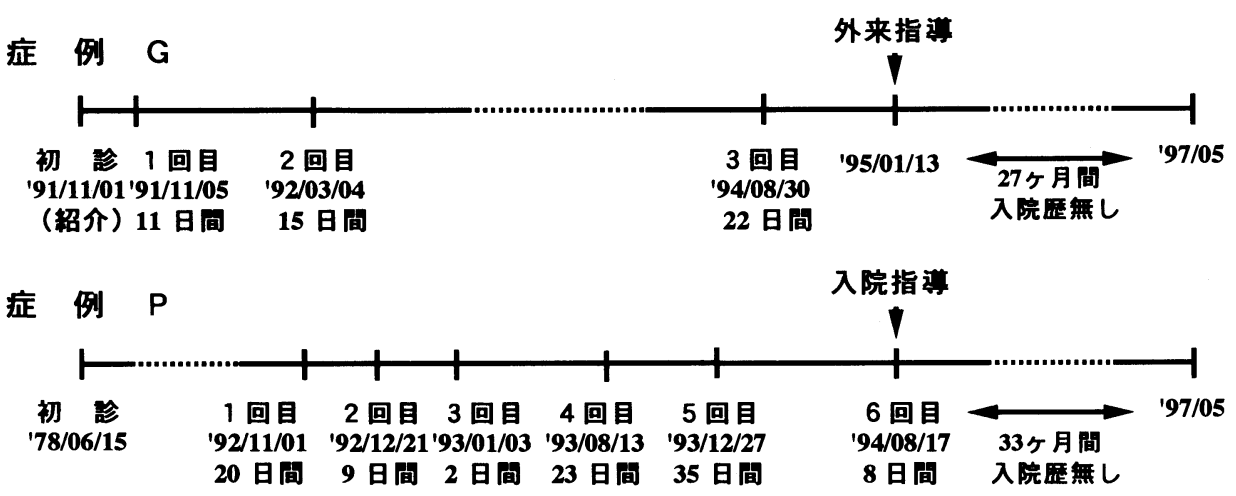

Fig. 1. 症例 $\mathrm{G}$, 症例 $\mathrm{P}$ の初診から現在までの入院歴 
していた, 吸入補助器具の使用法を良く知らなか った，また，発作時の MDI の使用法を良く知ら なかった，などの問題点が判明した。薬に対する 理解度についてであるが，調査時に服用していた 内服薬については，名前，用法は100\%，作用に ついてもオノンを気管支拡張薬と認識していた のみで，他に大きな問題はなかった。主治医も病 識の理解度が十分と判断し, 現在では症状に応じ たプレドニゾロンの頓服を指示していた，指導前 後では治療点数に差が無く，指導時にはプレドニ ゾロン $15 \mathrm{mg}$ を経口していたが，'95年10月より中 止することができた．指導後にも同年 2 月と 6 月 に合計 3 回の点滴治療を要する症状の悪化が認め
られたが，それ以降は定期受診のみでコントロー ルされていた (Fig. 2 ). ピークフローについても 1 日 3 回の測定を継続しており, 早朝と夕方の測 定結果を Fig. 3 に示した。症例 G はネブライ ザーの吸入に合わせて, その前後でピークフロー を測定していた。'96年10月には 2 時間程度の八 イキングも可能となり, 同年11月には 2 泊の旅行 を実施することもでき, 症状も安定し順調な経過 を示した。

2. 理解度の低い症例 (以下症例 P)

男性，年齢74才，気管支喘息は混合型， 重症に分類されており, 初診より16年経過してい た (Table 1)。これまで 5 回の入院歴があり，6

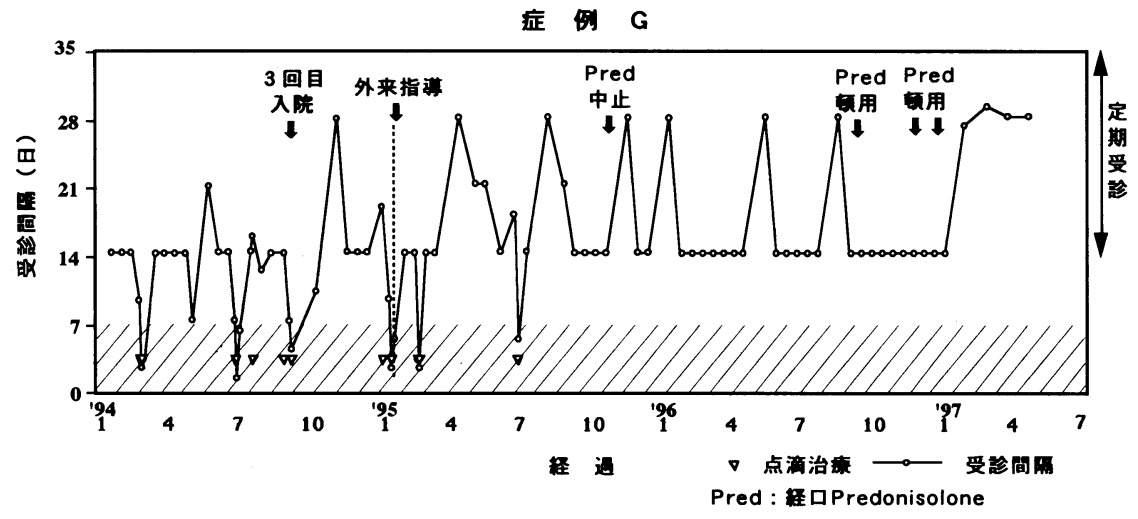

Fig. 2. 症例 G の通院状況ならびに外来における点滴治療状況 （斜線は 7 日以下であり，症状悪化による来院を示す）
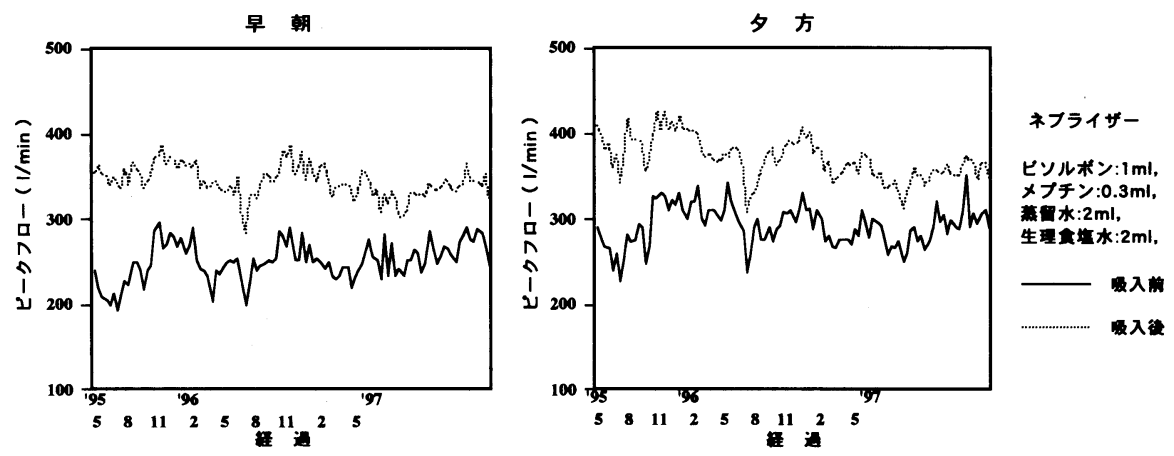

Fig. 3. 症例 G の早朝と夕方のピークフロー測定結果 (1週間の平均) 
回目の入院時に指導依頼があった(Fig. 3 ). 問題 点として, 自分勝手であり, これまでの入院でも 医師，看護婦の話を良く聞かず，自分の意見を一 方的に述べていた，薬に関しては，作用について はよく理解しておらず，特にステロイドについて は呼吸筋を強くする筋肉増強剤として認識してお り, プレドニゾロン錠（5 mg）を 1 日 2 錠朝服 用するように指示されていたが，勝手に 1 錠にし たり，2 錠にしたりしていた。同時にボルマチッ クを使用した BDPの吸入を指示されていたが， 吸入方法はあらかじめ息を吐き，ボルマチックに 吸入器をセットし，くわえて吸入しながら噴霧し ていた。これはMDIから噴霧される白い霧状の ガスを治療薬だと認識しており，噴霧されたガス は気化してすぐに見えなくなってしまうため，治 療薬が無くなると考え, ガスが見えなくなる前に 急いで吸入しようとしていたものである．当然吸 入速度は速くなっていた．ボルマチックを使用し ない直接吸入でも同様の問題があった。指導は最 初にボルマチックを使用した適切な吸入法につい て, 本人の前でデモを行いながら注意事項と理由 を説明した。次からは吸入法のチェックと内服薬 の指導を行い，8 日間の入院期間中に 5 回の指導 を行った. 本症例 P は薬の名前は理解していた が，用法については現在でも完全には理解できて おらず，作用については喘息の薬としての認識の みであり, 個々の薬剤の作用についての回答は得 られなかった。薬剤に関しては現在でも良く理解 しておらず, 病識についても薬剤と同様に理解度
が小さい症例である (Table 2). Table 3,Fig. 3 を見て分かるように，入院歴および救急外来受診 状況ともにかなり多い. 今回の入院中の服薬指導 以前は 1 年間に 2 回入院しており, その間, 外来 において点滴治療が 1 年間で13回を数え，28日毎 の定期受診では全く認められなかった。しかし， 服薬指導を行った 6 回目の入院以降は，'95年の 1 月から 3 月の冬季に 9 回, ’ 97 年の 1 月に 3 回 の点滴治療を受けているが, 現在まで喘息症状の 悪化による入院は認められなかった。 1 年後から は’97年 1 月に点滴治療を必要としたが, 最近で は28日毎の定期受診が続いている. 指導を行った 入院前後で治療内容に差はなかったが, 現在では 治療点数が減少しており, かなり良好にコント ロールされていた。

\section{考察}

気管支喘息は，他の慢性疾患と同様に疾患や薬 㓣に対する患者の理解度によって患者自身の QOL が左右されるため, 患者教育が非常に重要 になってくる7-9). 今回報告した症例 $\mathrm{G}$ はかなり 高いレベルの理解度を示しており, 指導後の経過 も順調であった. 症例 $\mathrm{G}$ は指導前後で治療点数 に違いはなかったが, その後経口のプレドニゾロ ンを中止することができた。それにともない内服 薬の追加があり, 服薬指導のみで現在の良好な状 態が達成されたわけではない。しかし，指導前の MDI の吸入法は適切な使用法とは言いがたく, 適切な使用法の指導とその実行による吸入ステロ

Table 2. 症例 $\mathrm{G}$ と症例 $\mathrm{P}$ の指導後の内服薬の理解度

\begin{tabular}{|c|c|c|c|c|}
\hline 空 语 & 薄品数 & 名前の理解宽 & 用法の理解度 & 作用の理解度 \\
\hline G & 7 & $100 \%(7 / 7)$ & $100 \%(7 / 7)$ & $86 \%(6 / 7)$ \\
\hline B & 6 & $100 \%(6 / 6)$ & $67 \%(4 / 6)$ & 践なし \\
\hline
\end{tabular}

Table 3. 症例 G と症例 $P$ の治療内容

\begin{tabular}{|c|c|c|c|c|c|c|c|c|}
\hline \multirow[t]{2}{*}{ 经 } & \multicolumn{2}{|c|}{ 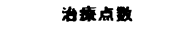 } & \multicolumn{2}{|c|}{ 经ロプレドニソロン } & \multicolumn{2}{|c|}{ 入䁃回数 } & \multicolumn{2}{|c|}{ 点海治关回致 } \\
\hline & 费略 & 现 在 & 指满固 & 积在 & 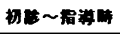 & 粗㴖策 & 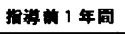 & 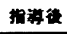 \\
\hline G & 44.5 & 22 & $7.5 \mathrm{mg}$ & 0 & 3 & 0 & 9 & 3 \\
\hline$P$ & 36 & 28 & $10 \mathrm{mg}$ & $10 \mathrm{mg}$ & 6 & 0 & 13 & 12 \\
\hline
\end{tabular}




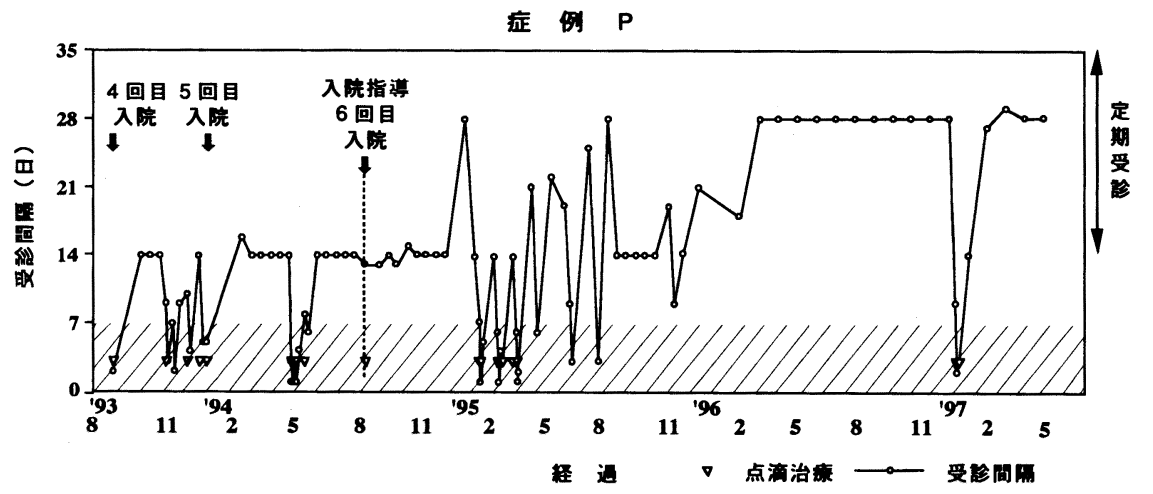

Fig. 4. 症例 P の通院状況ならびに外来における点滴治療状況

(斜線は 7 日以下であり，症状悪化による来院を示す）

イド剤の効果も大きいと考えられる，症例 $\mathrm{P} は$ 現在でも病識，薬骫に対する理解度がかなり低 く，服薬指導としては失敗例である。外来診察状 況から見て 6 回目の入院以降も特に冬季に症状の 悪化が認められた。しかし指導以前は 1 年間で指 導時入院を含めて 3 回入院していたが，その後は 入院加療を要するほどの増悪は認められておら ず， 1 年後以降は定期受診でコントロールできて おり，時間は要したものの，比較的良好な経過を たどっている，時間を要したのは，重症患者であ ったことのほかに，やはり薬剤に対する理解度が 低いため，特に内服薬のコンプライアンスが不良 だったことが推定される．理解度のみから考える とこのような経過は期待できない症例と考えられ る。症例 $\mathrm{P}$ は入院中に「発作の心配なく，夜眠 れるようになった」と話しており, 症状が軽快し たことを自覚できたことによって，その作用など はよく理解できなくともステロイド吸入の重要性 を体で体験し，そのために退院後も継続すること が出来たと考えられる，すなわち，服薬指導自体 としてはうまくいかなかったものの，MDIの使 用法に関しては患者に正しく伝えられた例と考え られる，気管支喘息と同様に慢性疾患に分類され る糖尿病や高血圧では，患者自身はこのような症 状の軽快を実感しにくく，気管支喘息に特徴的な ことと考えられる。しかし，特に理解度の低い患
者では症状が現れなくなると吸入を含めた薬剤の コンプライアンスの維持が難しく，症例 $\mathrm{P}$ にお いて 2 年後に症状の悪化が認められたのはコンプ ライアンスの低下があったと推定され, 理解度の 低い患者では，いかに継続するように指導するか が課題である。

気管支喘息ではピークフローの測定と喘息日誌 への症状の記録が治療にも自己管理にも重要であ $3^{10)}$ が，理解度の高い患者でも長期的な継続は 難しい．特に複数回指導してもその意義を理解で きない患者ではなおのこと困難である，ピークフ ローに関しては症例 $\mathrm{G}$ はネブライザーによる $\beta_{2}$ 刺激薬吸入の前後で測定している。これはピーク フローモニタリングの意義を良く理解してもらう ため，指導時に筆者が奖めたものである，症例 $\mathrm{G}$ ではネブライザー吸入後にピークフローが上昇し ている。これには2つの問題が含まれている，第 一には, 症例 $\mathrm{G}$ では $\beta_{2}$ 刺激薬吸入前の時点の值 が自己べストではなく, 吸入後のピークフロー值 を最大ピークフローとして認識する必要があるこ とである，ピークフローによる自己管理を行う際 に，自己ベストを100\%とし，信号になぞらえて 80\%以上をグリーンゾーン，50〜80\%をイエロー ゾーン，50\%以下をレッドゾーンとして，イエ ローゾーンでは自覚症状がないまでも薬剈の頓服 を指示したり, レッドゾーンでは早めの受診を指 


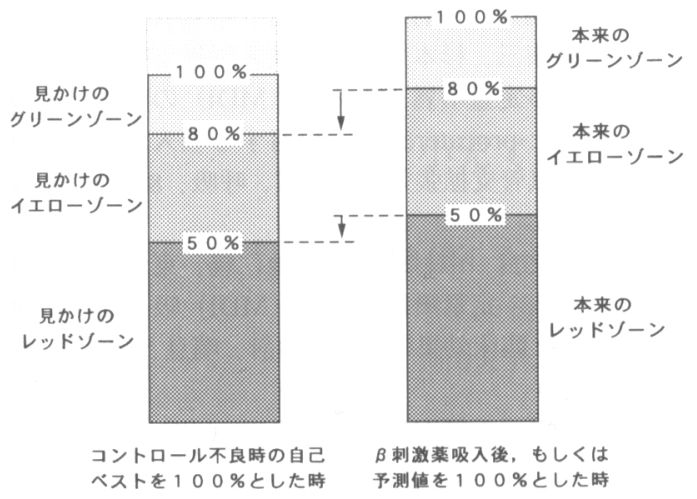

Fig. 5. コントロール不良時に $\beta_{2}$ 刺激薬吸入前の ピークフローの白己ベストを $100 \%$ とした 時と, $\beta 2$ 刺激薬吸入後もしくは予測值を 100\%とした時の違い

(基準となる $80 \%$ ，50\%の值が矢印の分小 さくなる)

示されている場合がある ${ }^{10)}$ 。この時, Fig. 5 に示 すように， $\beta_{2}$ 刺激薬吸入前の最大ピークフロー 值を自己ベストにしてしまうと各ゾーンの基準で ある80\%，50\%の值が低くなってしまい，受診す ベき時期が遅れてしまう危険性があり， $\beta_{2}$ 刺激 薬吸入後の測定值の自己ベストか予測ピークフ ロー值を100\%とする必要がある ${ }^{10)}$ 。これに対し て， $\beta_{2}$ 刺激薬を吸入してもピークフローがほと んど上昇しない場合がある。良好にコントロール されており， $\beta_{2}$ 刺激薬吸入前のピークフロ一值 が自己ベストの100\%に近い值を示守場合， $\beta 2$ 刺 激薬を吸入してもほとんど変化が認められないと しても問題はない。しかし， $\beta_{2}$ 刺激薬を定期的 に経口している場合などでは， $\beta 2$ 刺激薬を吸入 してもピークフロー值がほとんど上昇せず, 本来 基準とすべき自己べストより低い值を示す場合が ある。その様な場合では発作が起きた際に， $\beta_{2}$ 刺激薬の吸入による症状の軽快はあまり期待でき にくいことから，吸入を何回も繰り返すことはせ ずに可能な限り速やかに受診することを奨めなく てはならない。ピークフロー測定を継続している 気管支喘息患者に自己ベスト（もしくは予測ピー クフロー值）を確認することは重要であり，患者 がよく理解していない場合は主治医に確認し, 患
者に伝える必要がある。もう一点として，ステロ イドと $\beta_{2}$ 刺激薬の定期吸入を指示されている場 合の順番である。吸入操作に問題がないことを確 認すると共に, 先ず $\beta 2$ 刺激薬で気道を拡張して から，すなわちピークフロ一值が上昇してから， ステロイドを吸入した方が肺への吸入量が多くな りより効果的な使用法と考えられる。症例 $\mathrm{G}$ で はネブライザー療法をしているため 10 分以上経過 してからステロイドを吸入しているが， $\beta_{2}$ 刺激 薬とステロイドの MDIでの吸入では時間をおか ないで吸入している場合が多い。具体的によ゙れく らいの間隔をあげれば良いかと質問される時があ るが，实際に $\beta_{2}$ 刺激薬吸入後に 2 分間隔くらい でピークフローを測定し，どれくらい上昇するか を体験し，その間隔を決めることも動機付けとし て有効であると考えられる。またピークフローの 上昇が認められない場合は，MDIの吸入操作に 問題がある場合も考えられる。吸入操作に問題が ない場合は前述したように発作を起こした場合は $\beta_{2}$ 刺激薬の吸入に頼りすぎないように, 早めの 受診を奖める根拠となる。 $\beta_{2}$ 刺激薬の効果を ピークフローという目に見える形で体験すること は, 患者にピークフロー測定の意味を理解しても らう上で効果的であり，現在問題となっている喘 息死の防止にも有効と考えられる。

今回は, 薬剂, および疾患に対する理解度が両 極端な2 例について報告したが MDIの使用法の 指導内容は共通であり, 吸入操作, 吸入補助器具 (スペーサー）使用時の注意点, 交換時期, ステロ イドの MDIの説明，等である気管支喘息患者の 多くは今回の症例の間に位置すると考えられ, 理 解度を考虑した指導が必要である。しかし，ステ ロイド抵抗性の難治性喘息もあり，MDIの吸入 指導によって全ての喘息患者が良好な経過をたど るわけではなく, 薬剤のみならず, 生活面での指 導も重要である。またネブライザーに比較し， MDI は患者の生活の制限や負担が少ないとはい え，100点の履行を望むとすると，患者にはかな りの負担である。そのため理想的な吸入法はある 
ものの，患者によってはある程度のバリエーショ ンは許容されるべきと考えられる，完璧な吸入法 ではなく, ピークフローの改善を含め, 自覚症状 が改善する吸入法がその患者に最も受け入れられ る吸入法と考えられ，一方的な指導ではなく，患 者の使用法を理解した上での指導を繰り返すこと が重要であり, $\beta_{2}$ 刺激薬への過剩な依存の危険 性についても患者の注意を喚起する必要がある。

\section{引用文献}

1）牧野荘平監修, “成人喘息の診断と治療, 日本ア レルギー学会, アレルギー疾患治療ガイドライ ン，95年改訂版”,ライフサイエンス・メディカ 社, 東京, 1995, pp 16-18.

2）奥平博一,“気管支喘息治療ガイドーICR ガイド ラインをふまえて一，〕2気管支喘息の定義と発 生機序”, 宮城征四郎編, 中外医学社, 東京, 1995, pp.11-22.

3) M.T. Newhouse, M.B. Dolovich and P. Eng, Control of asthma by aerosols. N. Enl. J. Med., 315, 870-874 (1986).

4) 山本雅人, 山木健市, 高木健三, 小倉庸蔵, 長 谷川高明，鍋島俊隆，気管支喘息患者における 定量噴霧吸入器 (MDI) の使用上の問題点に関 する患者指導の有用性. 呼吸, 14, 189-194 (1995).

5) 木野稔也, 佐竹範夫, 安場広高, 川口英人, 楠 目馨, 大島駿作, 浅本仁, 故倉恵, 大山口渥,
中山昌彦, 中村昇, 比重行, 中橋弥生, 原洋, 中村泰三, 杉本幾久雄, 成人気管支喘息患者に おける定量噴霧式吸入器 (MDI) の吸入様式の 調查と procaterol 吸入に対する吸入方法指導前 後の気管支拡張効果の検討, 呼吸, 8, 1213-1221 (1989)

6) 小嶋文良, 中村秀範, 友池仁暢, 東海林徹, 仲 川義人，定量噴霧吸入剤（MDI）吸入指導の問 題点と臨床勃果に関する検討，喘息， 10, 95-102 (1997)

7) 谷本晋一, “COMMON DISEASE SERIES, 気管支喘息, 5 治療と患者教育, F1 生活指導”, 高久史䗪監修, 南江堂, 東京, 1991, pp.191-198.

8) F.E. Hargreave, J. Dolovich, M.T. Newhouse, -Editors, The assessment and treatment of asthma : Aconferen report, J. Allergy Clin, Immunol., 85, 1098-1111 (1990).

9) K. Tsukioka, S. Makino, T. Miyamoto, H. Mikawa, K. Ito, H. Tomioka, T. Takahashi, M. Adachi, M. Baba and K, Nishikawa, Questionnaire survey on asthma management of Japanese allergists I. Diagnosis, patient education and management, Allerogy Int., 45, 113116 (1996).

10）中島明雄，“気管支喘息治療ガイドーICR ガイ

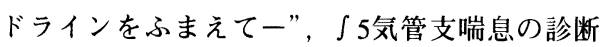
法. B 日常生活の管理, 2ピークフローによる自 己管理, 宮城征四郎編, 中外医学社, 東京, pp.148 $-153,1995$. 